\title{
The Use of Instagram Picture Series as Media to Improve Students' Ability in Writing Procedure Text
}

\author{
Vebriary Eka Rahmawati \\ STKIP PGRI Sidoarjo, e-mail: vebriaryeka@gmail.com
}

\section{Sulistyaningsih}

STKIP PGRI Sidoarjo, e-mail: sulistyaningsih3112@gmail.com

\begin{abstract}
This research aims to know whether the students' ability in writing procedure text could be improved through the use of Instagram picture series as teaching media. This is a classroom action research (CAR) implemented in two cycles, on the eleventh-grade students of Madrasah Aliyah NU Sidoarjo in 2019/2020 academic year. This research uses quasi-experimental design which has these criteria based on Mueller: 1). No random selection of subjects; 2). Pre-test both groups; 3). Experimental group receives new treatment; 4). Control group receive no treatment or the normal treatment; 5). Post-test both groups. The population is 126 students. The samples are ten students of XI MIPA 1 as the experimental group and ten students of XI MIPA 2 as the control group. The independent variable is Instagram picture series as media of teaching writing. The dependent variable is the students' ability in writing procedure text. In collecting the data, the researcher applied instrument: interview, questionnaire, Instagram application, writing pre-test and writing post-test. The data was analyzed statistically using $T$-test. The researcher examines two cycles of test. As the result in the first cycle, the pre-test average score of the control group is 44 and the experimental group is 45.5. In the first cycle of pot-test, the average score of the control group is 70 and the experimental group is 78. Both of them don't get the Kriteria Ketuntasan Minimum (KKM) or the level of basic competence score which is 80. So, the second cycle of post-test is held. As the result, the average score of the control group is 74 and the experimental group is 82.5. The next cycle of post-test isn't needed because the average score of the experimental group is already passed over the KKM. It means that, the use of Instagram picture series as teaching media has the significant positive impact to the improvement of the students' ability in writing procedure text.
\end{abstract}

Keywords: teaching writing skill, procedure text, teaching media, Instagram picture series

\section{INTRODUCTION}

Writing skill has the lowest percentage of achievement of all the communicative skills based on the average score observation toward the eleventh-grade students of Madrasah Aliyah NU Sidoarjo during 2019-2020 academic year. Moreover, the result of research has been showed that most of the students $(76.5 \%)$ found difficulty in writing. Some of them found difficulties in developing paragraph and finding proper vocabulary. 
Some of them did not recognize the correct spelling of some certain words. According to Hadfield (2004: v), there are some difficulties linked to the writing. Firstly, there is psychological difficulty in which the writer has to choose what the information the reader needs and how best to state this. Secondly, there is linguistic difficulty in that the language used in written language is diverse from that used in speech. Thirdly, there is cognitive difficulty in which that the students have to arrange their thought on paper. That is why writing is identified as the most difficult language skill to learn for a language learner. Thus, researcher focused on elaborates a method on teaching in order to improve the students' writing skill.

Harmer (2004:31) writes that teaching writing skill is different from teaching other skills. In addition, he argues that it is because "the nature of the writing process", "the need for accuracy in writing", and "the mental process that a student goes through when writing". Therefore, students who are writing are significantly different from the students who are speaking. Writing needs more time and accuracy. This is further supported by Raimes (1983:3) who states that "learning to write is not just a "natural" extension of learning to speak". Writing has more complexities than speaking. Students learn to speak in natural way, whereas students have to be taught at school to learn writing.

As in case of the eleventh-grade students of Madrasah Aliyah NU Sidoarjo in $2019 / 2020$ academic year, one of the lessons is about procedure text. It was found that the students' ability in writing procedure text was still far from what was estimated. From the result of the students' writing, the average score was 54.25. It was distressing because the material about procedure text is commonly found in students' daily life. There are many examples of procedure text. Those are directions which are used for giving instructions about where to go, recipes which are the set of instructions for preparing a food dish, and many appliance manuals.

Tim Fasilitator Bahasa Inggris (2006:79) says: "Teks prosedur adalah teks yang memberi instruksi atau informasi kepada pembaca." (Procedure text is a text which gives instructions or information to readers). It is the set of steps which should be completed in the right sequence to get the goal. The purpose of procedure text is to explain how something can be done. It means that in writing procedure text, the writer writes the actions which should have to do in chronological order. Gerot et. al (1994:86) 
states that the social function of procedure text is to describe how something is accomplished through a sequence of action or steps. In mastering procedure text, the students have to know the generic structure of procedure text. They are: (1). Goal: The goal can be the title of the text. It also can be an introductory paragraph; (2). Materials: In this part, the writer has to indicate what they will need to make something. The materials can be a list or paragraph; (3). Steps: In this part the writer has to indicate how something is accomplished through a sequence of actions or steps.

Based on the depth interviews, most of students said that the way of teaching was a dominant factor of their failure in writing. The teacher seldom taught writing to the students through writing process which only gave the students to write in a certain topic without any supervision and interesting teaching media. This fact revealed the significance of using media in teaching writing. Research reports that many students are more visual and tactile or kinesthetic or mixed than auditory (R. Dunn \& K. Dunn, 1992). This evidence states that people live in a world that is visually oriented. Most of the information that our brains process comes from non-verbal stimuli (images) and even verbal information is better processed when it is accompanied with visual stimuli.

Raimes (1983: 36) says that a picture sequence, such as comic strip, provides the subject matter for writing narrative and for speculating about the story beyond the pictures in the strip. A set of parallel pictures - pictures that show a similar scene or tell a similar story - provides material that offers guidance on vocabulary, sentence structure, and organization yet lets the students write about new subject matter. Wright (1997) suggests the use of picture series. According to him, pictures series are pictures which show some actions or events in chronological order. They tend to range from four to eight pictures. They usually tell some short of stories, but they may also be used to depict a process how to make something. These resources help teachers to contextualize language by connecting the classroom with the world outside its walls. They also encourage students to use the target language by providing support or a reference point to write or talk about. In this regard, he affirms that pictures "contribute to: 1) interest and motivation; 2) a sense of the context of the language; and 3) a specific reference point or stimulus".

A review of the literature led to the conclusion of adopting and implementing picture series technique to support the processes of teaching procedure text writing. 
Thus, the researcher expected the students improve their writing skill and develop a higher degree of participation in their learning process. At the end, there will be a significance improvement of their writing score. In addition, nowadays students are well-engaged with technology especially social media. Teachers should use this phenomenon to innovatively shape their strategies and approaches in language teaching as the new form of teaching media.

Cummins (2000: 539) says "rather than dismissing IT as many critical educators have tended to do, or lamenting its perspective impact on educational priorities, we should acknowledge the fundamental changes that IT is bringing to our societies and seek ways to use its power for transformative purposes". Moreover, the use of various applications through computers and smart phones has paved the way for teachers to innovatively shape their strategies and approaches in language teaching and learning. In fact, by applying social media in language classroom, namely Facebook, Instagram, Blogs, and Twitter, learners will be highly motivated to interact socially with their peers.

One of the popular photos sharing apps which used by almost of millennial students is Instagram. It serves as a great platform to share life moments with friends through a series of pictures. Teachers can utilize Instagram by asking them to post pictures related to objects and processes of procedure text. Bell (2013) conducted similar study using Instagram and disclosed that Instagram has played a major role in enhancing the subjects learning whereby communication took place in the form of expressing ideas and feelings in their captions in Instagram. Further, he claimed that written communication helps in the process of building up self-esteem and confidence in everyday lives.

In addition, Pratiwi (2019) accomplished a study about the effectiveness of media Instagram toward the student's speaking skills of tenth grader. Either Hape (2018) had run a study about the effect of Instagram to student's speaking. Both of their study found the positive impact of the use of Instagram toward the student's speaking skills. Thus, running the study about the use of Instagram as teaching media is the core similarity. The difference is this study focus on the student's writing ability. On the other hand, Ramadhani (2018) and Khusnita (2013) conducted a study about the use of Facebook application to improve student's writing skill. Both of them use Facebook 
application as teaching media which is different from this study. But the similarity is about teaching writing.

Based on the details above, the research of this paper is a classroom action research in order to improve the students' writing ability. The classroom action research focused on the improving students' writing ability especially in the form of procedure text by using Instagram picture series as teaching media. The objective of this study is to determine whether Instagram picture series as teaching media could improve the students' ability in writing procedure text.

\section{METHOD}

The method of this research was Classroom Action Research (CAR) model developed by Kemmis and Mc Taggart (1990:14) in Penelitian Tindakan (Action Research) written by Tim Pelatih Penelitian Tindakan (Action Research) Universitas Negeri Yogyakarta (2000:12). According to the model, the implementation of the action research includes four steps. They are planning, acting, observing and reflecting.

This research used quasi-experimental design which had these criteria based on Mueller (1992:38): 1). No random selection of subjects; 2). Pre-test both groups; 3). Experimental group receives new treatment; 4). Control group receive no treatment or the normal treatment; 5). Post-test both groups; Participants were equally assigned to experiment group and control group. The following procedures showed the research steps:

a. Step 1: Planning, the researcher was interviewing the teachers and students, giving questionnaire about writing, and giving pre-test on writing procedure text about making fried rice to both groups.

b. Step 2: Acting, the researcher applied the use of Instagram picture series as media on teaching writing procedure text to the experimental group. Teacher gave the example of writing procedure text by making caption and posting a picture series of making food or beverage. Then, asked the students to post their own picture and caption as the exercises. In other hand, the control group was taught without that media.

c. Step 3: Observing, the researcher gave the post-test writing procedure text about making their own favorite food or beverage to both groups. 
d. Step 4: Reflecting, the researcher analyzed to what extend the use of Instagram picture series as teaching media was successful based on the criteria designed.

The population of the research is the eleventh-grade students of Madrasah Aliyah NU Sidoarjo in academic year 2019-2020. The number of the students is 126 students which were divided into 4 classes.

Cluster sampling was taken as the technique. It requires groups or clusters in taking the sample based on the group that have already existed in the population. To make it easier, The two groups were taken as the sample. They were ten students of XI MIPA 1 as the experimental group and ten students of XI MIPA 2 as the control group.

The independent or predictor variable was Instagram picture series as media of teaching. The dependent or criterion variable was the students' ability in writing procedure text.

In collecting the data, several instruments such as interview, questionnaire, Instagram application, pre-test, and post-test were applied. Extracted data with the pretest and post-test instruments were assessed using a scoring rubric. The classification of the system score that the researcher used in the rubric went from 0 to 100 as follows: Poor: 0-20; Low: 21-40; Average: 41-60; Good: 61-80; Excellent: 81-100. Kriteria Ketuntasan Minimum (KKM) or the level of basic competence score was 80. So, the post-test was taken in few cycles until the average student's basic competence score could be gained.

The data was analyzed statistically using T-test. The intention was to know whether there was any significant improvement of students' writing ability. After that, the difference between the post-test and pre-test mean of the experimental group compared with the difference between the pre-test and post-test mean of the control group was examined. If the experimental group score was higher than the control group, it means that the independent variable was effective to improve the dependent variable.

\section{RESULT AND DISCUSSION}

\section{The Pre-test}

The pre-test was proposed to discover the basic writing skill of the students and it was given at the beginning of the intervention phase. It focused on the five components of writing namely; generic structure and transition (logical sequence and 
the use of connectors), ideas and content (exposure), grammar and syntax (structure), vocabulary (use of parts of the speech) and word spelling, and effort (punctual and visual) contained in the scoring rubric. Table 1 shows the scoring rubric used for both groups as follows:

Table 1: Scoring Rubric

\begin{tabular}{|c|c|c|c|c|c|}
\hline \multirow[b]{2}{*}{ Criterion } & \multicolumn{5}{|c|}{ Scoring Level } \\
\hline & $\begin{array}{l}\text { Poor } \\
(0-20)\end{array}$ & $\begin{array}{c}\text { Low } \\
(21-40)\end{array}$ & $\begin{array}{l}\text { Average } \\
(41-60)\end{array}$ & $\begin{array}{c}\text { Good } \\
(61-80)\end{array}$ & $\begin{array}{l}\text { Excellent } \\
(81-100)\end{array}$ \\
\hline $\begin{array}{l}\text { Idea \& } \\
\text { Content }\end{array}$ & $\begin{array}{l}\text { Both idea } \\
\text { and content } \\
\text { didn't } \\
\text { coherence } \\
\text { with the } \\
\text { topic }\end{array}$ & $\begin{array}{l}\text { Good idea but } \\
\text { content didn't } \\
\text { coherence } \\
\text { with the topic }\end{array}$ & $\begin{array}{l}\text { Ordinary idea } \\
\text { and content } \\
\text { coherence } \\
\text { with the topic }\end{array}$ & $\begin{array}{l}\text { Good idea } \\
\text { and content } \\
\text { coherence } \\
\text { with the topic }\end{array}$ & $\begin{array}{l}\text { Extraordinary } \\
\text { idea and } \\
\text { content } \\
\text { coherence } \\
\text { with the topic }\end{array}$ \\
\hline $\begin{array}{l}\text { Generic } \\
\text { Structure }\end{array}$ & $\begin{array}{c}\text { Title, } \\
\text { materials, } \\
\text { and steps, } \\
\text { weren't } \\
\text { written } \\
\text { completely, } \\
\text { correctly, } \\
\text { and in } \\
\text { chronologica } \\
\text { lly order }\end{array}$ & $\begin{array}{c}\text { Title, } \\
\text { materials, and } \\
\text { steps, were } \\
\text { written in } \\
\text { chronological } \\
\text { ly order but } \\
\text { they weren't } \\
\text { completely } \\
\text { and correctly }\end{array}$ & $\begin{array}{c}\text { Title, } \\
\text { materials, and } \\
\text { steps, were } \\
\text { written } \\
\text { completely } \\
\text { and in } \\
\text { chronological } \\
\text { ly order but } \\
\text { they weren't } \\
\text { correctly }\end{array}$ & $\begin{array}{c}\text { Title, } \\
\text { materials, and } \\
\text { steps, were } \\
\text { written } \\
\text { completely, } \\
\text { correctly, but } \\
\text { they weren't } \\
\text { in } \\
\text { chronological } \\
\text { ly order }\end{array}$ & $\begin{array}{c}\text { Title, } \\
\text { materials, and } \\
\text { steps, were } \\
\text { written } \\
\text { completely, } \\
\text { correctly, and } \\
\text { in } \\
\text { chronological } \\
\text { ly order }\end{array}$ \\
\hline $\begin{array}{r}\text { Gramm } \\
\text { Struct }\end{array}$ & $\begin{array}{l}\text { Both using } \\
\text { poor } \\
\text { grammar and } \\
\text { structure }\end{array}$ & $\begin{array}{c}\text { Using } \\
\text { average } \\
\text { grammar and } \\
\text { low structure }\end{array}$ & $\begin{array}{l}\text { Using good } \\
\text { grammar but } \\
\text { average } \\
\text { structure }\end{array}$ & $\begin{array}{l}\text { Both using } \\
\text { good } \\
\text { grammar and } \\
\text { structure }\end{array}$ & $\begin{array}{l}\text { Both using } \\
\text { excellent } \\
\text { grammar and } \\
\text { structure }\end{array}$ \\
\hline $\begin{array}{l}\text { Vocabulary } \\
\& \text { Spelling }\end{array}$ & $\begin{array}{c}\text { Both using } \\
\text { poor } \\
\text { vocabulary } \\
\text { and spelling }\end{array}$ & $\begin{array}{c}\text { Using } \\
\text { average } \\
\text { vocabulary } \\
\text { and low } \\
\text { spelling } \\
\end{array}$ & $\begin{array}{l}\text { Using good } \\
\text { vocabulary } \\
\text { but average } \\
\text { spelling }\end{array}$ & $\begin{array}{l}\text { Both using } \\
\text { good } \\
\text { vocabulary } \\
\text { and spelling }\end{array}$ & $\begin{array}{l}\text { Both using } \\
\text { excellent } \\
\text { vocabulary } \\
\text { and spelling }\end{array}$ \\
\hline Effort & $\begin{array}{c}\text { Late submit } \\
\text { and poor } \\
\text { visual }\end{array}$ & $\begin{array}{l}\text { On time } \\
\text { submit but } \\
\text { low visual }\end{array}$ & $\begin{array}{l}\text { Late submit } \\
\text { but good } \\
\text { visual }\end{array}$ & $\begin{array}{l}\text { On time } \\
\text { submit and } \\
\text { good visual }\end{array}$ & $\begin{array}{c}\text { On time } \\
\text { submit and } \\
\text { excellent } \\
\text { visual }\end{array}$ \\
\hline
\end{tabular}

Both the experimental group and the control group were asked to write a procedure text about making food or beverage. Both samples' name were initialized as SE means student's of the experimental group and SC means student's of the control group. Table 2 shows the pre-test scores for both groups as follows: 
Table 2: Pre-test Results of Experimental and Control Groups

\begin{tabular}{|c|c|c|c|}
\hline Experimental Group & Pre-Test Score & Control Group & Pre-Test Score \\
\hline SE1 & 45 & SC1 & 35 \\
\hline SE2 & 30 & SC2 & 45 \\
\hline SE3 & 50 & SC3 & 30 \\
\hline SE4 & 65 & SC4 & 55 \\
\hline SE5 & 45 & SC5 & 45 \\
\hline SE6 & 50 & SC6 & 50 \\
\hline SE7 & 35 & SC7 & 50 \\
\hline SE8 & 40 & SC8 & 25 \\
\hline SE9 & 50 & SC9 & 30 \\
\hline SE10 & 45 & SC10 & 75 \\
\hline
\end{tabular}

As can be seen, the scores of the experimental group showed three students with low performance, six students with average performance, and one student with good performance. On the other hand, the results from the control group showed one student with good performance, five student with average performance, and four students with low performance.

To calculate the pre-test Mean (X) or average score (the resulting figure from the sum of individual scores (x) divided by the number of students) the researcher used the following statistical formula $X=\sum x / n$, which symbols stand for: $(X)$ the mean or average, $\left(\sum\right)$ the sum that follows (x) individual scores, and (n) stands for the number of students.

Table 3: Pre-test Average Score

\begin{tabular}{|c|c|}
\hline Experimental group pre-test & Control group pre-test \\
Mean $X=\sum x / n$ & Mean $X=\sum x / n$ \\
$X=455 / 10 X=\mathbf{4 5 . 5}$ & $X=440 / 10 X=\mathbf{4 4}$ \\
\hline
\end{tabular}

The Mean (X) shows that the students from the experimental group had an average score of 45.5 , which means that the group, as a whole, only got the $45.5 \%$ of 100 points possible (45.5 out of 100). On the other hand, The Mean (X) of the control group shows that students got $44 \%$ of 100 points possible (44 out of 100). Both of them got the average score in pre-test. 


\section{The First Cycle of Post-test}

The post-test was given after intervention phase to the students. The control group was taught conventionally by giving the theory of procedure text and example of writing it on the whiteboard. Then, they were asked to write on the book about their own idea of procedure text of food or beverage as the topic. Meanwhile, the experimental group, different to the control group, was taught using Instagram picture series as teaching media. Teacher gave the example of writing procedure text by making caption and posting a picture series of making food or beverage. Then, asked the students to post their own picture and caption as the post-test. Once the groups done it, the researcher composed it, scored it with the rubric, and then analyzed the data. The analysis of the post-test scores of the experimental group showed that the amount of students with good performance was eight, and two students got excellent performance. On the other hand, the results from the control group showed one student with average performance, eight students with good performance and one with excellent performance. Table 4 shows the post-test scores for both groups as follows:

Table 4: The First Cycle of Post-test Results of Experimental and Control Groups

\begin{tabular}{|c|c|c|c|}
\hline Experimental Group & Post-Test Score & Control Group & Post-Test Score \\
\hline SE1 & 80 & SC1 & 70 \\
\hline SE2 & 70 & SC2 & 65 \\
\hline SE3 & 80 & SC3 & 65 \\
\hline SE4 & 75 & SC4 & 65 \\
\hline SE5 & 80 & SC5 & 75 \\
\hline SE6 & 80 & SC6 & 65 \\
\hline SE7 & 70 & SC7 & 65 \\
\hline SE8 & 85 & SC8 & 60 \\
\hline SE9 & 85 & SC9 & 80 \\
\hline SE10 & 75 & SC10 & 90 \\
\hline
\end{tabular}

To calculate the post-test Mean (X) or average score the researcher used the same procedures as in the pre-test.

Table 5: The First Cycle of Post-test Average Score

\begin{tabular}{|c|c|}
\hline Experimental group post-test & Control group post-test \\
Mean $X=\sum \mathrm{x} / \mathrm{n}$ & Mean $\mathrm{X}=\sum \mathrm{x} / \mathrm{n}$ \\
$\mathrm{X}=780 / 10 \mathrm{X}=\mathbf{7 8}$ & $\mathrm{X}=700 / 10 \mathrm{X}=\mathbf{7 0}$ \\
\hline
\end{tabular}


The Mean (X) shows that the students from the experimental group got an average score of 78 , which means that the group got the $78 \%$ of 100 points possible. On the other hand, The Mean (X) of the control group shows that students got an average score of 70 , which means that the group got the $70 \%$ of 100 points possible. Both of them got the good average score in post-test. But both of them didn't gain the Kriteria Ketuntasan Minimum (KKM) or the level of basic competence score which is $80 \%$ of 100 points. So, the second cycle of post-test was taken.

\section{The Second Cycle of Post-test}

The second cycle of post-test was given after intervention phase to the students again as be done in the first cycle before. The control group was taught conventionally as before in the first cycle. The experimental group, different to the control group, was taught using Instagram picture series as teaching media again. Teacher gave the authentic example of writing procedure text by making caption and posting a picture series of making food or beverages. Different from the first cycle, the students were asked to make the authentic ones. It means that getting the picture from internet wasn't allowed. They had to create the original ideas and pictures from their daily activity related to the topic. Then, they had to post their own pictures and captions as the posttest. Once the groups done it, the researcher composed it, scored it with the rubric, and then analyzed the data.

The analysis of the post-test scores of the experimental group showed that the amount of students with good performance was five, and five students got excellent performance. On the other hand, the results from the control group showed nine students with good performance and one with excellent performance. Table 6 shows the post-test scores for both groups as follows: 
Table 6: The Second Cycle of Post-test Results of Experimental and Control Groups

\begin{tabular}{|c|c|c|c|}
\hline Experimental Group & Post-Test Score & Control Group & Post-Test Score \\
\hline SE1 & 85 & SC1 & 75 \\
\hline SE2 & 75 & SC2 & 75 \\
\hline SE3 & 80 & SC3 & 70 \\
\hline SE4 & 80 & SC4 & 70 \\
\hline SE5 & 80 & SC5 & 75 \\
\hline SE6 & 85 & SC6 & 70 \\
\hline SE7 & 75 & SC7 & 70 \\
\hline SE8 & 90 & SC8 & 65 \\
\hline SE9 & 90 & SC9 & 80 \\
\hline SE10 & 85 & SC10 & 90 \\
\hline
\end{tabular}

To calculate the post-test Mean (X) or average score the researcher used the same procedures as in the first cycle of post-test.

Table 7: The Second Cycle of Post-test Average Score

\begin{tabular}{|c|c|}
\hline Experimental group post-test & Control group post-test \\
Mean $X=\sum \mathrm{x} / \mathrm{n}$ & Mean $\mathrm{X}=\sum \mathrm{x} / \mathrm{n}$ \\
$\mathrm{X}=825 / 10 \mathrm{X}=\mathbf{8 2 . 5}$ & $\mathrm{X}=740 / 10 \mathrm{X}=\mathbf{7 4}$ \\
\hline
\end{tabular}

The Mean (X) shows that the students from the experimental group got an average score of 82.5 , which means that the group got the $82.5 \%$ of 100 points possible. On the other hand, The Mean (X) of the control group shows that students got an average score of 74 , which means that the group got the $74 \%$ of 100 points possible. The control group got the good average score in the second cycle of post test. Meanwhile, the experimental group got the excellence one.

Finally, in this second cycle of post-test, the experimental group successfully gained $82.5 \%$ of 100 points passed over the Kriteria Ketuntasan Minimum (KKM) or the level of basic competence score which is $80 \%$ of 100 points. The next cycle of posttest wasn't needed because the average score of the experimental group was already passed over the $K K M$.

\section{The Comparison between Pre-test and the Second Cycle of Post-test Results}

A comparative analysis of the findings from the pre-test and the second cycle of post test exposed a significant growth in the average performance or mean of both 
groups. But, the percentage growth of the experimental group is higher than the control group. The experimental group went from 45.5 to 82.5 , showing a growth of $44.85 \%$. On the other hand, the control group went from 44 to 74 , with a total growth of $40.54 \%$. To calculate the growth the researcher used this following formula:

$$
\text { Percentage of Growth }=\frac{(\text { Post test-Pre test })}{\text { Post test }} \times 100
$$

Table 8: Pre-test and Second Cycle of Post-test Mean (X) Percentage of Growth

\begin{tabular}{|c|c|c|c|}
\hline \multicolumn{4}{|c|}{ Average Score (Mean) } \\
\hline Group of Students & Pre-test & $2^{\text {nd }}$ Post-test & Growth \\
\hline Experimental & 45.5 & 82.5 & $44.85 \%$ \\
\hline Control & 44 & 74 & $40.54 \%$ \\
\hline
\end{tabular}

Based on Table 8, the percentage growth's margin between experimental group and control group is $44.85 \%-40.54 \%=4.31 \%$. That margin percentage is quite significance compared with the null hypothesis standard margin $0.5 \%$. This finding revealed that the use of Instagram picture series as teaching media could improve the students' ability in writing procedure text.

\section{CONCLUSION}

In a nutshell, the use of Instagram picture series as teaching media is an appropriate strategy for eleventh grade students of Madrasah Aliyah NU Sidoarjo to improve their ability in writing procedure text. This Classroom Action Research using quasi-experimental design which is done in two cycles successfully reveal it. The following procedures in each cycle is used to gain the data: 1). No random selection of subjects; 2). Pre-test both groups; 3). Experimental group receives new treatment; 4). Control group receive the normal treatment; 5). Post-test both groups. Then, the data is analyzed statistically using T-test.

As the result in the first cycle, the pre-test average score of the control group is 44 and the experimental group is 45.5. In the first cycle of pot-test, the average score of the control group is 70 and the experimental group is 78 . Both of them don't get the Kriteria Ketuntasan Minimum (KKM) or the level of basic competence score which is 80. So, the second cycle of post-test is held. As the result, the average score of the control group is 74 and the experimental group is 82.5 . The next cycle of post-test isn't 
needed because the average score of the experimental group is already passed over the $K K M$

A comparative analysis of the results from the pre-test and the second cycle of post test expose a significant growth in the average performance or mean of both groups. Based on them, the percentage growth's margin between experimental group and control group is $44.85 \%-40.54 \%=4.31 \%$. That margin percentage is quite significance compared with the null hypothesis standard margin $0.5 \%$. It means that, the use of Instagram picture series as teaching media has the significant positive impact to the improvement of the students' ability in writing procedure text.

\section{REFERENCES}

Bell, M. A. 2013. Picture this! Using Instagram with students. Internet@Schools, 20(4), pp. 23-25.

Cummins, J. 2000. Language, Power and Pedagogy: Bilingual Children in the Crossfire. Clevedon: Multilingual Matters.

Dunn, R., \& Dunn, K. (1992). Teaching secondary students through their individual learning styles: Practical approaches for grades 7-12. Boston: Allyn and Bacon.

Gerot, Linda \& Peter Wignel. 1994. Making Sense of Functional Grammar. Sydney: Gerd Stabler.

Hadfield, Charles \& Jill Hadfield. 2004. Writing Games. Edinburg: Longman Pearson Education Limited.

Hape, Nissa M. 2018. The Effect of Instagram to Students' Speaking at the Paradise English Course of Kampung Inggris Kediri. Kediri: University of Nusantara PGRI Kediri.

Harmer, J. 2004. How to Teach Writing. England: Pearson Education Limited.

Khusnita, Dafi. 2013. The Use of Facebook to Improve Student's Skill and Increase Their Motivation in Writing Recount Text. Semarang: State University of Semarang

Mueller, Delbert. 1992. An Interactive Guide to Educational Research. Needham Heights: Concordia University. 
Pratiwi, Mira F. 2019. The Effectiveness of Media Instagram Toward The Students' Speaking Skills of Tenth Grade in SMAN 4 Malang. Language-Edu: Journal of Teaching and Learning. Volume 8, Number 2. Accessed on May, 012020 at http://riset.unisma.ac.id/index.php/LANG/article/view/2914

Ramadhani, Pungki. 2018. Using Facebook Comments in Teaching Writing Skill. Sidoarjo: FKIP UMSIDA Sidoarjo.

Raimes, A. 1983. Technique in Teaching Writing. New York: Oxford University Press.

Tim Fasilitator Bahasa Inggris. 2006. Asyik Belajar dengan PAKEM (Pembelajaran Aktif, Kreatif, Efektif, dan Menyenangkan). Jakarta: Managing Basic Education.

Tim Pelatih Penelitian Tindakan (Action Research) Universitas Negeri Yogyakarta. 2000. Penelitian Tindakan (Action Research). Yogyakarta: Direktorat Pendidikan Menengah dan Lembaga Penelitian Universitas Negeri Yogyakarta.

Wright, A. 1990. Pictures for language learning. Cambridge: Cambridge University Press. 